\title{
PRAGMATIST PERSPECTIVES ON THEOLOGICAL AND RELIGIOUS REALISM
}

\author{
SAMI PIHLSTRÖM \\ Helsinki Collegium for Advanced Studies \& University of Jyväskylä
}

\begin{abstract}
This essay first applies the general issue of realism vs. antirealism to theology and the philosophy of religion, distinguishing between several different 'levels' of the realism dispute in this context. A pragmatic approach to the problem of realism regarding religion and theology is sketched and tentatively defended. The similarities and differences of scientific realism, on the one hand, and religious and/or theological realism, on the other hand, are thereby also illuminated. The concept of recognition is shown to be crucially relevant to the issue of realism especially in its pragmatist articulation.
\end{abstract}

\section{INTRODUCTION}

When examining the problems and prospects of realism in religion and theology, we should begin by contextualizing the realism vs. antirealism debate (or, better, debates) into different local problem areas. ${ }^{1}$ I will begin with some brief remarks on relatively standard varieties of realism (or the problem of realism) and then move on to applications of these realisms in the field of the philosophy of religion. Toward the end of the essay, I will introduce my own preferred pragmatist perspective on the realism controversy, enriched with a notion not usually employed by pragmatist philosophers, namely, the notion of recognition.

${ }^{1}$ See, for instance, Ilkka Niiniluoto, Critical Scientific Realism (Oxford and New York: Oxford University Press, 1999), for a very helpful classification of different forms of realism. A major recent collection of articles on various aspects of the realism issue is Kenneth R. Westphal (ed.), Realism, Science, and Pragmatism (London and New York: Routledge, 2014). 
First of all, as is well known, realism has been a major theme in the philosophy of science over the past few decades, and continues to be actively discussed by philosophers of science. According to scientific realism, there 'really' are unobservable theoretical entities postulated in scientific theories (or, in a somewhat more careful formulation, it is up to the world itself to determine whether or not there are such entities); those theories have truth-values independently of our knowledge and experience; and scientific progress may be understood as convergence toward mind-independently objective ('correspondence') truth about the world. These features of scientific realism may, furthermore, have more specific applications in sub-fields such as the philosophy of physics, the philosophy of biology, or the philosophy of history. Another interesting example is mathematical realism, according to which numbers and other mathematical entities and/or structures somehow mind-independently exist (possibly in a Platonic world of eternal Forms), and our mathematical truths about them are mind-independently what they are.

Clearly, the realism debate is not restricted to the philosophy of science. In ethics (or, rather, metaethics), moral realism has been a major topic of dispute for decades, too. This controversy is about whether there are objective moral values and/or mind-independent moral truths about 'moral facts' (or, perhaps better, about the nature of the moral values there mind-independently are, or are not). Just as the scientific realist believes in the objective truth-values of scientific theories, even when they postulate observation-transcendent theoretical entities and structures, and the antirealist denies that theories have such truth-values, especially insofar as they are about the unobservable, the moral realist maintains that moral statements are objectively true or false (even though their truth or falsehood cannot, of course, be immediately perceived), while the antirealist argues that this is not the case (for instance, for the reason that moral 'statements' are not really factual statements at all but moral discourse is, instead, mere expression of attitudes, such as emotions). More generally, axiological realism is the view that values (including not only moral but also aesthetic, epistemic, and other values) are real, instead of being mere human projections or constructions.

Highly important dimensions of the realism issue are also discussed and debated in relation to other traditional core areas of philosophy, such as general metaphysics. For example, the modal realist seeks to formulate a realistic account of the modalities, i.e., possibilities and necessities. According to such realism, possibilities, for instance, are 'real' - or there 
are real possible worlds in addition to the actual world. A related - and ancient - form of realism is realism about universals, that is, the kind of realism about the Forms that may (or may not) be instantiated in particular objects that classical philosophers like Plato and Aristotle (in their different ways) maintained. Metaphysicians and epistemologists have also debated about realism about the past (and about future, or about temporality in general). The question here is whether past (and future) objects and events really mind- and discourse-independently exist and whether statements about the past - analogously to statements about the unobservable world in science - have objective truth-values. And many other examples of realism and antirealism in different subfields of philosophy can easily be distinguished. These are all, as we may say, different local versions of realism (vs. antirealism).

These contextualizations or localizations of the problem of realism are to be distinguished from the quite different distinctions between the various philosophical dimensions of the general or global realism issue that concerns the mind- and discourse-independence (vs. dependence) of reality in general. The ontological realism question is, of course, whether there is a mind- and language-independent world at all. Epistemologically, we may ask whether we can know something (or anything) about such an independent world. The semantic realist, furthermore, maintains that we can refer to such a world by using our language and/or concepts; according to such realism, our statements about the world are mind-independently true or false, and truth is typically construed as correspondence with the way things are. All these differentiations between the dimensions of realism and antirealism can also be applied more locally to the kind of issues preliminarily listed above. For example, scientific or modal realism can be discussed from the point of view of the ontological, epistemological, or semantic dimension of the realism issue. ${ }^{2}$

2 There has also been some debate over which dimension is the most important one. Michael Devitt is famous for the view that realism is a purely ontological thesis about the mind-independent existence of certain kinds of entities, either about something in general or about specific classes of entities such as the theoretical entities of science. See Devitt, Realism and Truth, 2nd ed. (Oxford and Cambridge, MA: Blackwell, 1991; 1st ed. 1984). This contrasts with Michael Dummett's equally well-known view that realism is a semantic issue about whether statements of certain types (e.g., about the past) have truth values that are objectively determined. See, e.g., Michael Dummett, The Seas of Language (Oxford: Clarendon Press, 1996). 
The concept of independence - as well as, conversely, dependence - is crucially important for the entire realism discussion. According to typical forms of realism, the world is (largely) independent of various things: minds or subjects; their experiences, perceptions, and observations; concepts or conceptual schemes; language, linguistic frameworks, or language-games; theories and models; scientific paradigms; perspectives or points of view; traditions; practices; and so forth. I will mostly just use 'mind-independent' as a shorthand for all these and other standard forms of independence (to be contrasted with the relevant kinds of dependence). Furthermore, it should be noted that, in the realism discussion, the relevant concept of (in)dependence is, at least primarily, ontological: A is ontologically dependent on B, if and only if A cannot (or could not) exist unless B exists. Different modal forces are of course invoked insofar as this definition is formulated in terms of 'cannot' or 'could not', respectively. This ontological notion of (in)dependence, in both stronger ('could not') and weaker ('cannot') modal versions, is to be distinguished from, for example, logical (in)dependence and causal (in)dependence. Statements or theories are logically independent of each other insofar as there is no logical entailment between them. (It is hard to say in what sense exactly the notions of logical dependence and independence could even be applied to the relation between, say, a statement and a non-linguistic fact, insofar as entailment is a relation between logical, propositional, and/or linguistic entities.) Regarding causal dependence and independence, we may say that, for example, a table is causally dependent on its maker but ontologically independent of her/him because it can continue to exist when s/he dies. When made, its existence no more ontologically presupposes its maker's existence even though antirealists may deny that the table, or anything, could exist entirely independently of human beings' thought, language, or experience.

Now that we have reached a preliminary conception of what kinds of realism there are, globally and locally, we should also get clear about the different varieties of antirealism. There are, in fact, many quite distinct antirealisms, or several ways of being an antirealist, both globally and locally. An easy way of listing such antirealisms would be to just list the denials of the corresponding realisms. However, let me briefly indicate in what sense some traditionally best-known antirealisms are opposed to realism. 
First, idealism is often represented as a version of antirealism. The problem here, however, is that idealists can also be realists, depending on how exactly these views are defined (there will be more to be said on this matter below in relation to pragmatism). Another key version of antirealism is, as is well known, relativism, according to which the way the world is is relative to, for instance, conceptual schemes or perspectives. There is, then, no way the world is 'in itself', perspective- or schemeindependently. Relativism is often relatively close to constructivism (which can also be compared to at least some forms of idealism): we 'construct' the world in and through our perspectival language, discourse, or conceptualization, and it is precisely for this reason that there is no non-relative existence at all. A quite different version of antirealism is empiricism (as a view discussed primarily in the philosophy of science), which maintains that only the observable world is real and that metaphysical speculations about the existence of unobservables should be abandoned. According to such empiricism (e.g., instrumentalism), scientific theories should be interpreted as mere instruments of calculation and prediction, instead of sets of mind-independently true or false statements about (unobservable) reality. Furthermore, nominalism (in the universals debate) is a form of antirealism in the sense of claiming that there are no mind- and language-independent universals, only particulars. Yet, nominalists could be realists in other ways; for example, several influential contemporary scientific realists are nominalists in metaphysics. The varieties of antirealism are by no means exhausted by these well-known and much disputed doctrines.

Finally, an important distinction ought to be drawn between antirealisms and nonrealisms. Not all denials of realism can be simply classified as antirealisms. For example, Richard Rorty has repeatedly claimed that his 'antirepresentationalism' leads us beyond the entire issue of realism, which in his view crucially depends on representationalist assumptions, that is, on the idea that the business of language-use is to represent non-linguistic and mind-independent reality and that it may succeed or fail in this task. ${ }^{3}$ Another influential nonrealist position in the philosophy of science in particular was formulated in the 1980s by Arthur Fine with the label 'NOA', 'the natural ontological attitude'. The 'NOAist' just accepts the ontological postulations of science, avoiding any further

${ }^{3}$ See, e.g., Richard Rorty, Truth and Progress (Cambridge: Cambridge University Press, 1998). 
philosophical speculation, problematization, or interpretation of them. ${ }^{4}$ These nonrealisms, which can be regarded as close relatives, cannot be discussed here, but I want to note that the version of pragmatic realism to be articulated and tentatively defended below is not committed to the kind of Rortyan antirepresentationalist neopragmatism that has given a fertile context to nonrealism. It is realism itself that we can and should, I think, save through pragmatism, even though the realism thus saved will have to be a thoroughly revised one. (Similarly, pragmatism may and should accommodate its own specific - pragmatic - notion of representation instead of giving up representationalism altogether.)

After this preliminary survey, we should take a closer look at how the different forms of realism and antirealism - or, more modestly, some key variants of them - are applicable to the philosophy of religion and theology.

\section{APPLYING REALISM(S) TO THEOLOGY AND RELIGION}

The problem of realism in theology and religion obviously concerns the (in)dependence of the world and/or objects purportedly referred to in religious and/or theological language-use. These objects could include God, souls, angels, and many other things traditionally postulated in religious practices and theological theorization. At least in principle, it is possible to be a local realist about some of these ontological commitments while being an antirealist about some others: for instance, one could be a realist about God's existence while being an antirealist about angels. That is, one could maintain that it is a mind-independently objective matter whether or not God exists, and which properties God has (if He does exist), while maintaining that statements about the existence of angels, or about their properties, do not have mind-independently determined objective truth-values. Note, however, that at least according to most formulations of realism and antirealism, one does not qualify as an antirealist about God if one just denies God's existence - or as an antirealist about angels if one just denies their existence, because one may very well be a realist about the features of the mind-independent

\footnotetext{
${ }^{4}$ See Arthur Fine, The Shaky Game, 2nd ed. (Chicago and London: The University of Chicago Press, 1996; 1st ed. 1986). I critically discuss Fine's NOA from the point of view of the philosophy of religion in Sami Pihlström, 'A Pragmatic Critique of Three Kinds of Religious Naturalism', Method and Theory in the Study of Religion, 17 (2005), 177-218.
} 
world itself that make it the case that there is no God, or no angels. Atheism is not antirealism but typically presupposes realism.

There are, to be more precise, different 'levels' of realism about religion. At least four such levels can be distinguished. It is helpful to introduce these distinctions by referring to the relevant relations between practices of language-use and the relevant objects that those practices of language-use can be supposed to be about. First, we may apply the realism issue to religious language itself - that is, to the relation between religious language and its objects (whatever they are). Secondly, we may speak about realism and antirealism in relation to theological (e.g., Christian, Jewish, or Islamic) language and its objects. Thirdly, we may distinguish the language of non-confessional religious studies (or comparative religion) - and its objects - from the first two levels. Fourthly, and finally, the language of philosophy of religion - and its objects, whatever they might be - is a yet higher 'meta-level' context for investigating realism in relation to religion.

Accordingly, when asking whether to be realists or antirealists about religious matters, we may ask this question at four different levels (at least), that is, as the question of whether there are, e.g., mindindependent truths about objective reality in (1) religion, (2) theology, (3) religious studies, and (4) philosophy of religion. Let us pursue these questions in turn.

First, according to religious realism, the objects of religious beliefs and/or statements (e.g., God) exist, or fail to exist, independently of religious language-use. That is to say, God is real or unreal independently of whether you, I, or anyone believes Him to be real. If God exists, He will continue to exist even if no one believes in His existence. ${ }^{5}$ And conversely, if God does not exist, He will not come into existence no matter how strongly $\mathrm{He}$ is believed in. Religious antirealism denies

${ }^{5}$ In a more careful presentation of religious realism (and antirealism), it would be important to distinguish between reality and existence. One might, for instance, construe God along the lines of Charles S. Peirce's 'extreme scholastic realism' as a 'real general', arguing that God does not exist in the way in which particular objects, such as stones or galaxies, exist but is nevertheless real in the way in which general tendencies, habits, or modalities (e.g., laws of nature) are. Accordingly, God would be something like a general world-process instead of being a mere individual entity existing in the world. On Peirce's realism about generality, see a number of influential essays collected in The Essential Peirce, 2 vols, The Peirce Edition Project, ed. Nathan Houser et al. (Bloomington: Indiana University Press, 1992-98), including the famous 1871 'Berkeley Review' (in vol. 1) and several later essays on pragmatism and pragmaticism (in vol. 2). 
this independence and regards God as mind-dependent in some sense, for instance, as a construction based on religious language-use, or a discourse-independent construal, as some postmodernist orientations in philosophy of religion might put it.

Secondly, according to theological realism, certain theological doctrines are mind-independently true or false, depending only on the way the (religious) world objectively is. For example, the doctrine of divine simplicity - that is, the view that God is the simplest possible object, which may also be taken to entail the view that all of God's attributes, such as His absolute goodness and omnipotence, are identical to God himself - is either true or false depending on the true metaphysical nature of God. Either God is the way this doctrine says He is, or He is not that way; it is not up to the theological doctrine to determine what God's metaphysical nature is, but it is the other way round. The truth or falsity of the doctrine is grounded in the nature of the world, and of God. The theological antirealist, again, denies such independence, maintaining that the truth or falsity of the kind of doctrines at issue here depends on their theological formulation, or our theological perspectives on God and the world.

It may, however, be difficult to draw the exact line between religious and theological language-use, and the corresponding versions of realism (and antirealism), although generally theological doctrines could be regarded as meta-level interpretations of actual religious beliefs. Christological, pneumatological, soteriological, and other sophisticated interpretations of Christian beliefs - regarding, respectively, the nature of Christ, the Holy Spirit, and salvation - can be regarded as doctrines belonging to this set of meta-level theological construals of 'first-order' religious beliefs. A 'normal' believer need not, and typically does not, have the kind of theological sophistication that the formulation and understanding of these doctrines requires. One's entitlement to religious realism cannot therefore depend on one's being a realist (or an antirealist) about the meta-level theological doctrines.

One could, then, in principle, be a religious realist about, say, the existence of Christ but an antirealist about some more specific theological views, such as the doctrine of Christ's second coming. But could one be a theological realist while being a religious antirealist? This would, presumably, be an awkward position. One could hardly reasonably maintain that the truth-values of claims about Christ's second coming are mind-independent and objective while denying such 
mind-independence and objectivity to claims about God's existence. Furthermore, it may also be difficult to determine what it is to be a realist about Christ if one is not committed to the theological doctrines that define Christ. Which specific doctrines should be taken to play such a defining role? This may be a matter of theological dispute. Does Christ (or, for that matter, God) have only essential properties or also contingent ones? Could one, then, be an antirealist about a doctrine such as Christ's second coming, let alone a highly central doctrine such as Christ's resurrection (or, say, Christ's two natures), without also being an antirealist at the basic religious level about God? ${ }^{6}$

The third level to be discussed is the problem of realism about religious studies. This may be compared to the more general realism issue that arises in the human sciences (such as history, anthropology, cultural studies, literary theory, and other fields): is the human cultural and social world also mind-independently and objectively the way it is (more or less like the scientific realist about natural science believes the natural world to be), so that truths about it are determined independently of our theories and discourses, or is it somehow a human cultural-theoretical construct, possibly in a stronger sense than the natural world? The age-old nature vs. culture distinction is of course in some sense presupposed here. Scientific realism in the natural sciences must certainly be distinguished from realism about the humanities and social sciences. There is clearly a sense in which human culture and society are human and therefore mind-dependent constructs, but the intended sense of 'independence' should be understood correctly here; certainly there is no a priori reason why one could not apply realism across the board, not only in the sciences but also in the humanities. Even if it may not be easy to regard human sciences such as literary theory as pursuing objective truth in

6 Theological and religious views and problems may also influence our views on realism in other domains: for example, the problem of evil has typically been discussed presupposing moral realism; it may look quite different if one begins from moral antirealism. Cf. T.L. Carson, 'Axiology, Realism, and the Problem of Evil', Philosophy and Phenomenological Research, 75 (2007), 349-368. Carson argues that J.L. Mackie (a famous critic of moral realism and theism) seems to assume the truth of moral realism in his discussion of the problem of evil (see Mackie, The Miracle of Theism: Arguments For and Against the Existence of God (Oxford and New York: Oxford University Press, 1983)), because he assumes that pain or suffering is mind-independently bad or evil. For a discussion of the problem of evil in relation to pragmatist philosophy of religion, see Sami Pihlström, Pragmatic Pluralism and the Problem of God (New York: Fordham University Press, 2013), chapter 5. 
the same sense in which we may regard physics or biology as pursuing objective truth, there is no principled reason why our statements and theories in these different fields could not be objectively true or false depending on the ways in which the (admittedly very different) objects of study are. The objects of the human sciences are not independent of human thought and action, but they could still be independent of the theorist's or scholar's views and experiences in a sense relevantly similar to the mind-independence of physical particles.

Now, insofar as religious studies (or comparative religion) is part of the 'human sciences' in the same sense as history or anthropology are, the realism debate in the latter is directly applicable to the former, or the former is only a special case of the latter. Of course it must be kept in mind that the social and cultural world of religion, any more than the cultural world generally, is not 'mind-independent' in the same sense as physical nature is (according to the realist); yet, again, it can (arguably) be independent of the researchers' - the religious studies scholars' - minds, or of their theories, in an analogous sense. ${ }^{7}$

The relation between religious studies and theology is far from clear, however. Theological doctrines, such as (again) divine simplicity or Christ's second coming, could be and often are seen as 'confessional': to be a Christian is to maintain that these and many other doctrines about God, Christ, and related matters are true (though it may be open to further discussion what it practically means in religious life to be committed to their truth). ${ }^{8}$ However, theological doctrines can

${ }^{7}$ Does the 'miracle argument', which we owe to philosophers of science such as Hilary Putnam and Richard Boyd, work in theology or religious studies? This further question, though highly interesting, cannot be pursued here. The miracle argument - as analyzed and defended, for instance, in Putnam's Mathematics, Matter, and Method (Cambridge: Cambridge University Press, 1975) - is the argument according to which only realism can adequately explain the fact that science has been enormously successful in its practical applications, including technology. Unless the theories in advanced sciences were at least approximately true and unless the theoretical terms of those theories (at least approximately) referred to real entities in the world, this success of science would be a 'miracle', an unexplainable cosmic coincidence. The reason why there may be no clear analogy to this argument in either theology or religious studies is that there may be no clearly identifiable empirical success to be explained. At least the question about the empirical and/or practical success of these disciplines is much less straightforward.

${ }^{8}$ Perhaps one could, after all, be a realist about theological doctrines in the sense of claiming that they are objectively true or false, while being an antirealist about their implementations in actual religious life, viewing such life as a matter of symbols and rituals rather than any propositionally expressible theological commitments. 
also be studied entirely 'neutrally' and non-confessionally as objects of religious believers' (and theologians') beliefs - and the one who engages in such non-confessional study need not at all engage in the practices, either religious or theological, within which those beliefs are actually maintained, or taken to be true. Thus, it may be a result of theological inquiry that a religious group $\mathrm{X}$ maintains, or has maintained at some point in its history, a doctrine $\mathrm{Y}$ (e.g., as interpreted in a certain way). Is this still theology, or is it, rather, religious studies? Or perhaps comparative religion? The disciplinary identities may be extremely unclear here. In the Nordic countries, for instance, theology is usually understood as a non-confessional study of religious beliefs, doctrines, practices, their history, etc. The theologian need not be committed to the doctrines s/he studies, or to any religious ideas. This is the case, for instance, at the University of Helsinki Faculty of Theology in Finland. In some other religious and theological traditions, it may be harder to understand, or even inconceivable, that one could engage in theology while avoiding religious commitments altogether.

If theology can be pursued without commitments to any Christian or other theological doctrines, then there is no fundamental distinction between theology and religious studies, nor between the relevant versions of the realism vs. antirealism debate. The same general points about realism in the human sciences will then apply to religious studies and theology alike. However, if theology is interpreted confessionally, then one could be a realist about a theological doctrine while being an antirealist about a meta-level interpretation and/or explanation of that doctrine within non-confessional religious studies (comparative religion). But is the converse position coherent? Could one be a realist about a nonconfessional interpretation of a religious doctrine about which one is a theological antirealist? I am tempted to answer affirmatively. One can of course be a realist about, for example, historical issues regarding the emergence, prevalence, and maintenance of certain theological ideas and/or views in certain historical or contemporary communities while rejecting theological realism about those ideas themselves. One need not be a realist about, say, angels, even if one is a strong realist about religious studies examining people's and communities' beliefs in angels. Even so, it might be more natural to maintain a realistic commitment across the board, at both levels.

Fourthly, how about philosophy (of religion)? Things get even more complicated when the philosophy of religion enters the picture 
to supplement the practices of religion, theology, and religious studies. Philosophy of religion can be more or less directly concerned with religious concepts and beliefs, but it can also examine their relation to both theological interpretations and non-confessional explanations and accounts offered within religious studies. We may here also want to distinguish, on the one hand, philosophy of religion, and on the other hand, philosophy of science - or something corresponding to the philosophy of science - as applied to (i) the 'science' of theology (if it can be regarded as a science in any sense) and to (ii) the inquiries within religious studies.

Does philosophy of religion have any 'objects of its own'? Can one be a realist (or an antirealist) about the language used within the philosophy of religion, and the relation between that language-use and its relevant objects? Arguably, the complex relations between the objects of religion, theology, and religious studies, and the relations between the different ways (different languages) of speaking about those objects, can be among the 'objects' of the philosophy of religion.

The more general question, not to be answered here, is whether there can be mind-independent and objective facts about philosophical theories and their actual or potential objects at all. Is there, moreover, a mind-independent and objective truth about, say, realism itself (or other topics in the philosophy of religion, such as the nature of evil)? That is, is it objectively and mind-independently true or false that realism holds, or does not hold, about religious views, about theological doctrines, or about the results of religious studies inquiries? (Are the statements made in this essay on realism mind-independently and objectively true or false, accurately representing a subject matter independent of them?) The 'reality' studied by the philosophy of religion should include all the levels of the realism debate: religious and theological entities (e.g., God), as well as relevant human activities within which such entities - and questions concerning their existence - are referred to, spoken about, and inquired into.

As has become clear through this discussion, however preliminary it must remain, there is a certain analogy between scientific realism and the different realisms applied to religion and theology. However, even though this analogy may be helpful, it may also be seriously misleading; at least we should be careful to avoid too easy analogies. The entire attempt to discuss theological realism by means of an analogy to scientific realism is, arguably, problematic, as it presupposes an evidentialist view of 
theology as relevantly comparable to science. According to evidentialism, religious beliefs - as well as, by extension, their theological meta-level interpretations - need to be evaluated on the basis of the rationally acceptable evidence that can be presented in their favour, just as one would generally evaluate scientific (and everyday) beliefs. Realism and antirealism cannot, then, be strictly separated from the evidentialism $v s$. fideism issue (although these two issues are in principle distinct); this is part of a broadly Kantian entanglement of metaphysics and epistemology. Pragmatism (which we will discuss below in a bit more detail) rejects evidentialism, while also rejecting straightforward versions of fideism, and hence also the direct scientific realism analogy.

When developing a pragmatist approach to the realism debate (in science, religion, and theology - and elsewhere), the genuine differences between all these practices must be appreciated. This, we might say, is to embrace a 'practical realism' about the realism debate itself. ${ }^{9}$

\section{A PRAGMATIST APPROACH TO THE REALISM DEBATE}

The philosophical tradition of pragmatism offers a fresh perspective on the realism vs. antirealism issue. The rest of this paper is devoted to showing - inevitably only very briefly - what the pragmatist contribution might be, and how it could, especially in the philosophy of religion, be enriched by considerations adapted from the theory of recognition.

The so-called classical pragmatists - Charles S. Peirce, William James, and John Dewey ${ }^{10}$ - all defended views that can be regarded as to some

${ }^{9}$ Cf. Rein Vihalemm, 'Practical Realism: Against Standard Scientific Realism and Anti-Realism', Studia Philosophia Estonica, 5:2 (2012), 7-22. For example, the criticism of the 'realist aims' of theology by Wang-Yen Lee (see Lee, 'A Pragmatic Case against Pragmatic Theological Realism', The Heythrop Journal, 50 (2009), 479-494) by analogy to constructive empiricism starts from the problematic assumption that theological theories are to be seen as 'scientific', in principle open to similar empirical considerations as scientific theories. I am not sure that 'theological constructive empiricism' even makes any sense (even though constructive empiricism about religious studies might make sense, while I would certainly not recommend maintaining that, or any, version of constructive empiricism as an alternative to (pragmatic) scientific realism). For a treatment of pragmatism as a third option between evidentialism and fideism, as well as realism and antirealism, in the philosophy of religion, see Pihlström, Pragmatic Pluralism and the Problem of God (cited above).

${ }^{10}$ For a collection of historical and systematic discussions of pragmatism, old and new, see Sami Pihlström (ed.), The Continuum Companion to Pragmatism (London and New York: Continuum, 2011). 
extent realistic but to some extent anti- or nonrealistic - or, if not strictly speaking antirealistic, at least in some sense idealistic or constructivist (even though it also needs to be pointed out that none of the classical pragmatists was really tempted to defend any form of relativism). The tensions we find in these thinkers' positions regarding realism and its alternatives illuminate the ways in which the realism issue has been and continues to be at the heart of the pragmatist tradition in philosophy. ${ }^{11}$ A similar tension seems to be at work in contemporary neopragmatism, that is, in the thought of philosophers like Richard Rorty and Hilary Putnam. In theology and philosophy of religion specifically, this tradition has more recently been represented by figures such as Eberhard Herrmann and Dirk-Martin Grube. ${ }^{12}$

Pragmatism can be seen as a philosophical approach seeking to mediate between realism and antirealism in a manner comparable to Immanuel Kant's attempt to argue that empirical realism is compatible with (and even requires) transcendental idealism. More critically, this means that the realism vs. antirealism tension is indeed inevitably present in pragmatism, both classical and 'neo'. However, the pragmatists have typically attempted to move beyond this tension in interesting ways. The relevant tension that needs to be dealt with here can be briefly expressed as follows: the world is (empirically) independent of us, but its independence is itself a human construct within our purposive practices

${ }^{11}$ See Pihlström, Pragmatic Pluralism and the Problem of God, as well as my earlier works on pragmatism and realism, including Sami Pihlström, 'Structuring the World: The Issue of Realism and the Nature of Ontological Problems in Classical and Contemporary Pragmatism', Acta Philosophica Fennica, 59 (Helsinki: The Philosophical Society of Finland, 1996). See also Sami Pihlström, 'Pragmatic Realism', forthcoming in Westphal (ed.), Realism, Science, and Pragmatism (cited above).

12 See, e.g., Eberhard Herrmann, 'A Pragmatic Realist Philosophy of Religion', Ars Disputandi, 3 (2003), available at: <www.arsdisputandi.org>. See also Herrmann, 'Realism, Semantics and Religion', in Timo Koistinen and Tommi Lehtonen (eds.), Philosophical Studies in Religion, Metaphysics and Ethics (Helsinki: Luther-Agricola Society, 1997), 77-94. In this essay, Herrmann draws on Putnam in arguing that sciences and 'views of life' such as religions have different functions and hence different notions of truth. In the latter, being true means not 'to be the case' (as in science) but to be 'true to life' in a qualitative sense, with true expressions being 'adequate expressions of what it means to be a human being' (p. 92). See also, for an excellent recent contribution to a re-evaluation of the pragmatist perspective on theological and religious realism along broadly Putnamian lines, Niek Brunsveld, The Many Faces of Religious Truth: Developing Hilary Putnam's Pragmatic Pluralism into an Alternative for Religious Realism and Antirealism (Diss., University of Utrecht, The Netherlands, 2012). 
and may receive different forms within different practices. Moreover, the world and whatever exists or is real within it can exhibit a number of different practice-laden forms of mind-independence. For example, the mind-independence of electrons, of historical facts, and of God (if, indeed, all of these entities or structures are mind-independently real) are all quite different kinds of mind-independence, and it makes sense to speak about these different kinds only within different purposive practices in which they play some functional roles. The practice of physical science within which the independent existence of electrons is at issue does not, presumably, have any role for God to play, but on the other hand the religious person's prayer addressed to a God believed to be real independently of that activity of praying hardly presupposes that electrons, or any other pieces of the material world, are real. There is no need to reduce all these to the same essence of what it means to be mind-independent. Pragmatic realism - if we may use such a label - is itself 'practice-involving', not just a view maintained for 'practical' (e.g., non-theoretical or instrumental) reasons. Rearticulating realism itself, like religion, in terms of human practices is the key program of pragmatic realism. This program is very different from the more radical neopragmatist program of giving up realism, or even the issue of realism altogether (as Rorty suggests).

Some contemporary pragmatists, including Eberhard Herrmann, have suggested that the realism issue in religion and theology can be fruitfully articulated in terms of Putnam's distinction between internal and metaphysical realism. ${ }^{13}$ According to Herrmann, Putnam's internal realism can plausibly be used as a model for realism in theology and religion. While I am not entirely convinced by this proposal, let me briefly recapitulate the main points of Putnam's form of realism; this will only serve as an example of an influential and theologically relevant version of neopragmatism here.

One of Putnam's characterizations of the difference between internal and metaphysical realism is based on his observation that our perceptions and conceptions of the world are relative to language and/or conceptual schemes, since 'elements of what we call "language" or "mind" penetrate so deeply into what we call "reality" that the very project of representing ourselves as being "mappers" of something "language-independent" is

13 See the publications cited in the previous note, including Brunsveld's 2012 dissertation. 
fatally compromised from the very start. ${ }^{34}$ This formulation seems to employ a relatively straightforward idea of language-dependence (or mind-dependence). The contrasting view, metaphysical realism, maintains that we can, in principle at least, theorize about a languageand mind-independent world an sich, as it is independently of our thoughts and language-use. The basic point of internal realism is that there is no such external, disengaged viewpoint available for us. All our engagements with reality begin from an internal standpoint that already involves human practices and linguistic categorizations of reality. One way of summarizing this distinction between two kinds of realism is by saying that metaphysical realism dreams of a theocentric conception of the world, while internal realism argues that we human beings cannot get rid of our anthropocentric, and therefore inevitably limited and contextual, ways of coping with reality. This corresponds to the way in which the world has, in the pragmatist tradition more generally, been seen as a 'human world', as in a way plastic or malleable to human beings' purposeful actions and practice-related conceptual categorization. ${ }^{15}$

A pragmatist perspective on theological realism can be summarized in terms of the following key points, which arguably represent the main strengths of pragmatism in comparison to more standard versions of theological/religious realism and antirealism. First, pragmatism should be firmly set against scientism (e.g., strong and reductive forms of scientific realism): non-scientific perspectives and practices are equally important for us as scientific ones. Secondly, even if scientific realism in its strongest forms cannot be accepted, there is, nevertheless, a kind of realistic spirit operative in pragmatism. ${ }^{16}$ This is especially clear in

${ }^{14}$ Hilary Putnam, Realism with a Human Face, ed. James Conant (Cambridge, MA and London: Harvard University Press, 1990), p. 28.

15 See, e.g., William James, Pragmatism: A New Name for Some Old Ways of Thinking (1907), eds. Frederick H. Burkhardt, Fredson Bowers, and Ignas K. Skrupskelis (Cambridge, MA and London: Harvard University Press, 1975), chapter 8. On the distinction between theocentric and anthropocentric perspectives as parallel to the Kantian distinction between transcendental realism and transcendental idealism, see Henry E. Allison, Kant's Transcendental Idealism: An Interpretation and Defense a Revised and Enlarged Edition (New Haven, CT and London: Yale University Press, 2004; 1st ed. 1983). On Putnam's approach to metaphysical issues in the philosophy of religion, see also Hilary Putnam, 'God and the Philosophers', Midwest Studies in Philosophy, 31 (1997), 175-187.

${ }^{16}$ I am adopting the phrase 'realistic spirit' from Cora Diamond's Wittgensteininspired work; see her The Realistic Spirit (Cambridge, MA and London: The MIT Press, 
James's reflections on the brute reality of pain, suffering, evil, and death; these ethically pregnant themes seem to be, for the Jamesian pragmatist, in the end much more important than purely theoretical construals of realism vs. antirealism. More generally, thirdly, it can be argued that ethics and metaphysics are deeply entangled in pragmatism, both in early pragmatism such as James's and in more recent pragmatism such as Putnam's. According to these pragmatists, there is a sense in which our metaphysical construals and categorizations of reality depend on our ethical perspectives; thus, the relevant realism issues are also entangled. ${ }^{17}$

These basic points about pragmatism correspond to the ways in which I see pragmatism as a major promise in the philosophy of religion more generally. Epistemically, pragmatism seeks to move beyond the evidentialism vs. fideism controversy and to thereby transform the debates on the rationality vs. irrationality and objectivity vs. subjectivity of religious belief (both of which are closely related to, while not being identical with, the realism vs. antirealism issue). Existentially, pragmatism, at least in the form in which I am hoping to develop it, seeks to move beyond 'theodicist' attempts to solve the problem of evil; responding to the reality of evil - in a 'realistic spirit' - is thereby seen as a major challenge for any ethically serious religious and theological thought. ${ }^{18}$ The epistemic and the existential challenges in contemporary philosophy of religion are, of course, entangled - as should be clear, for instance, on the basis of the undeniable relevance of moral realism and antirealism to the problem of evil.

There are also further pragmatist ideas that may seem to be only indirectly related to realism but are nevertheless relevant to it. For example, most pragmatists have been non-reductive naturalists of some kind; the key example of such a position in the philosophy of religion would be

1991). See also Sami Pihlström, 'Pragmatic Pluralism and Realism in the Philosophy of Religion', in Henrik Rydenfelt and Sami Pihlström (eds.), William James on Religion (Basingstoke: Palgrave, 2013), pp. 78-107.

17 See Sami Pihlström, Pragmatist Metaphysics: An Essay on the Ethical Grounds of Ontology (London: Continuum, 2009). Putnam's key work in this area is Hilary Putnam, The Collapse of the Fact/Value Dichotomy and Other Essays (Cambridge, MA and London: Harvard University Press, 2002).

${ }^{18}$ I briefly deal with these epistemic and existential challenges in Sami Pihlström, 'Rationality, Recognition, and Anti-Theodicy: On the Promise of Pragmatist Philosophy of Religion', Pragmatism Today, 4:2 (2013), available at: <http://www.pragmatismtoday. eu>. See also Pihlström, Pragmatic Pluralism and the Problem of God, chapter 5. 
Dewey's pragmatic religious naturalism. ${ }^{19}$ Moreover, pragmatists' general attempt to occupy a middle ground between realism and antirealism leads to the need to examine the complex relation between relativism and pluralism. It must be somehow secured that the idea of a plurality of acceptable (and, possibly, equally rational) human practices and perspectives does not lead to a full-blown relativism according to which there are in the end no normative standards governing human reasonuse and theorization at all, or no reasonable choices to be made between rival perspectives. Finally, the relations between religion, ethics, and politics need to be taken very seriously by any pragmatist who claims that philosophy of religion ought to make a difference to the ways in which human beings live in this world. That is, what is the place of religion in the public sphere, and how should it, possibly, be reconsidered? While this issue may not seem to be closely related to the problem of realism, it can be argued that it does in the end have a deep connection with that issue. Ethical and political realism need to be reconsidered from the point of view of the problem of introducing, or reintroducing, religious and theological perspectives into public discussions. (This paper will not take any stand on this set of problems; I am just mentioning this topic as an example of the way in which pragmatist philosophy of religion can seek to be truly practically relevant.)

All these aspects of pragmatist philosophy of religion have dimensions that touch the realism debate. For example, should we settle the realism issue (at some specific level) before making any commitments regarding 'religion in the public sphere'? Or can we leave the realism issue open? Furthermore, when developing pragmatic religious or theological realism, the multi-level structure of the realism issue examined in the previous section must be kept in mind: one could be a pragmatic realist about religion while being an antirealist about theology or religious studies, or vice versa. These commitments arguably require holistic pragmatic assessment. ${ }^{20}$

\footnotetext{
${ }^{19}$ See John Dewey, A Common Faith (New Haven, CT and London: Yale University Press, 1991; first published 1934).

${ }^{20}$ The 'holistic pragmatism' defended by Morton White, e.g., in his A Philosophy of Culture: The Scope of Holistic Pragmatism (Princeton, NJ: Princeton University Press, 2002), could at this point be invoked as a systematization of pragmatist philosophy of religion and pragmatist methodology in general. That must remain to be discussed on another occasion, however.
} 


\section{RECOGNITION AND RECOGNITION-TRANSCENDENCE}

The pragmatist philosopher of religion may, furthermore, apply the (broadly Hegelian) concept of recognition (Anerkennung): it may be argued that our religious identities are largely based on relations of mutual recognition - loosely employing the concept of recognition as articulated by Axel Honneth and his many followers and critics. ${ }^{21}$ One key idea here, keeping in mind the general entanglement of ethics and metaphysics in pragmatism, is that the ethical relations of recognition may be primary to the ontological relations constituting our identities. Could the relations between realists and antirealists also be analyzed in terms of recognition? In particular, how should we make sense of the idea of recognizing a person (or a community) as being committed to shared norms of rational thought and/or inquiry (that is, as a member of the same community of inquirers) $?^{22}$ Furthermore, how exactly should we distinguish between the notions of recognition, tolerance, and agreement - and make sense of the fact that these are, indeed, different notions, playing somewhat different roles in our habits of action and in our practices of sharing an ethically problematic world with other human beings?

Instead of attempting to provide answers to these questions, let alone a general treatment of recognition in the philosophy of religion, even just pragmatist philosophy of religion, let me in the rest of this essay take up the more specific theme concerning recognition and recognitiontranscendence in pragmatic realism. There is a sense in which antirealism, e.g., relativism or fideism about religion (both culminating in some kind of rejection of objectivity), makes recognition too easy: we can certainly (mutually) recognize each other as utterers of 'inarticulate sounds' or as mere 'enunciators' whose words have no normatively evaluable content. ${ }^{23}$

${ }^{21}$ Cf. Axel Honneth, Kampfum Anerkennung, 2nd ed. (Frankfurt am Main: Suhrkamp, 2003; first published 1992). For a recent attempt to apply the concept of recognition to theology, see Risto Saarinen, 'Anerkennungstheorien und ökumenische Theologie', in T. Bremer (ed.), Ökumene - überdacht (Quaestiones disputatae 259, Freiburg: Herder, 2013), pp. 237-261. I make my own first preliminary attempt to connect pragmatism and the theory of recognition with each other in the field of philosophy of religion in Pihlström, 'Rationality, Recognition, and Anti-Theodicy' (cited above).

${ }^{22}$ Arguably, the Kantian idea of a moral community is based on a mutual recognition among autonomous agents necessary for this (and therefore recognition is not only a Hegelian notion). I am grateful to Philip Rossi for a discussion of this point.

${ }^{23} \mathrm{I}$ am here helping myself to phrases familiar from Wittgensteinian and Putnamian contexts. Cf., e.g., Hilary Putnam, Words and Life, ed. James Conant (Cambridge, MA and London: Harvard University Press, 1994). 
This is what relativism, arguably, ultimately leads to. But when it comes to judgments with normatively evaluable content, objectivity becomes a challenge for us, something to be pursued in the 'space of reasons. ${ }^{24}$ Then, if we slide toward the other extreme - strong objectivity and realism (e.g., metaphysical realism in Putnam's sense, as briefly sketched above) - recognition may become too difficult: we would presumably first have to settle whether religious beliefs can be mind-independently true or false, before being able to decide whether a person or a group is able to be 'objective' in this area, and to thereby recognize them as rational thinkers. These are in the end questions about the possibility of recognizing others as inquirers, as inhabitants of the space of reasons. But how objective do we have to be qua inquirers? Recognizing ourselves as responsible to others in our inquiries can be argued to be a matter of recognizing our own fallibility and dependence on our membership in a community of inquirers. ${ }^{25}$

In the semantically oriented realism debate in particular (as developed by Putnam as well as Michael Dummett), recognition-transcendent truths have played a major role: to be a realist is to accept that (possibly) recognition-transcendent statements (e.g., 'There are no intelligent extraterrestrials') are mind-independently determinately objectively true or false, in principle just like statements whose truth-values it is easy to recognize (e.g., 'There is a cup of coffee on the table'); to be an antirealist is to deny this. ${ }^{26}$ Call this form of recognition-transcendence RT1. One could also invoke recognition-transcendence in another sense: if someone is 'beyond recognition' in the sense that $\mathrm{s} /$ he cannot be recognized as

${ }^{24}$ For an influential contemporary employment of the notion of the space of reasons, which we owe to Wilfrid Sellars, see John McDowell, Mind and World, 2nd ed. (Cambridge, MA and London: Harvard University Press, 1996; 1st ed. 1994).

${ }^{25}$ Cf., e.g., Kenneth R. Westphal, 'Rational Justification and Mutual Recognition in Substantive Domains', Dialogue, 52 (2013), 1-40. According to Westphal, this is a transcendental condition for the possibility of rational judgment. (Hence, this argument leads to a form of Kantian pragmatism.)

${ }^{26}$ The kind of (arguably antirealistic) epistemic concept of truth associated with Putnam's internal-realist-phase theory of truth as idealized rational acceptability, or epistemic justification in ideal conditions, in a way denies (at least strong) recognitiontranscendence. As is clear in his later writings, Putnam has come to reject such an epistemic theory of truth altogether. See Hilary Putnam, Philosophy in an Age of Science, eds. Mario de Caro and David Macarthur (Cambridge, MA and London: Harvard University Press, 2012); in this new volume, he avoids connecting these issues with religion and theology, though. 
something or someone in particular, under some normative description (e.g., as an inquirer, or perhaps more specifically as an inquirer into recognition-transcendent truths), we may regard this as another kind of recognition-transcendence. Call this RT2.

Now, can we recognize (in the sense of RT2) someone as a recognizer (or non-recognizer) of (some or all) potential recognition-transcendent truths (in the sense of RT1)? Or should we recognize (RT2) each other as potential recognizers (RT1) of there being recognition-transcendent truths (RT1)? There is, then, a certain kind of iterability and variability of RT1 and RT2, yielding a potentially indefinite complexity of relations of recognition and recognition-transcendence.

What does this result teach us? Perhaps it only shows that metaphysical issues concerning RT1 need the ethically relevant perspective of RT2 a perspective and a notion of recognition directed at other human beings instead of either mere truths (or facts) or mere principles of rationality or other norms. This also necessarily includes recognizing our own fallibility and dependence on other inquirers. ${ }^{27}$

Moreover, a point worth emphasizing here is that religious truths, if there are any, might be (humanly) recognition-transcendent. A reasonable form of religious realism, or theological realism (as well as, by extension, a reasonable form of realism regarding religious studies), needs to account for this idea. Even more strongly, whether there are any religious truths may be recognition-transcendent. It may, arguably, be a feature of our religious practices and their theological interpretations and articulations that these limits of human recognition abilities need to be recognized by those (successfully) engaging in such practices or seeking to theologically articulate and understand them (or at least by anyone who could be recognized as successfully doing so). At least, at the meta-level, it needs to be recognized that it might be recognitiontranscendent whether religious truths (if there are any) are recognitiontranscendent or not. There are, as can easily be seen, several versions of recognition and recognition-transcendence at work here; a more detailed theory of this matter would have to sort out their relations much more comprehensively. Any such theory, if adequate, will also need to deal with the key distinction between recognizing people and recognizing something else - truths, principles, criteria, norms, etc. - which in this

27 Cf. Westphal, 'Rational Justification and Mutual Recognition in Substantive Domains', cited above. 
case amounts to the distinction between recognizing people as recognizers (or non-recognizers) or truths and/or their recognition-transcendence, on the one hand, and recognizing recognition-transcendence itself, or there being recognition-transcendent truths.

\section{CONCLUSION}

There are, we may conclude, pragmatist resources still not in full use in the general realism debate (and in its various localizations and contextualizations, for example, in the philosophy of science and in the discussions of social ontology), as well as in the specific debate(s) on realism vs. antirealism regarding religion, theology, and religious studies. Pragmatism may be uniquely able to critically analyze the relations between these levels of the debate by contextualizing them in the underlying purposive practices and the needs or interests they serve (viz., religion, theology, scientific inquiry, philosophy itself). Pragmatism may, indeed, be the only perspective on the realism debate that can seriously make sense of the idea that 'mind-independence' itself is not just a realistic 'given' but a human practice-laden construct. The concept of recognition, moreover, can be employed to enrich the pragmatist approach to the realism issue. This is a further Kantian-inspired (and certainly not only Hegelian) development of pragmatism.

This final point about pragmatic realism being a fundamentally Kantian way of thinking, in philosophy of religion and elsewhere, needs to be taken seriously. ${ }^{28}$ This even extends to the need to take seriously a pragmatic analogy of Kantian 'things in themselves' (or 'noumena') in this area. Putnam himself, who generally seeks to avoid strong metaphysical commitments, points out that he is 'not inclined to scoff at the idea of a noumenal ground behind the dualities of experience, even if all attempts to talk about it lead to antinomies'; furthermore, he adds that because 'one cannot talk about the transcendent or even deny its existence without paradox, one's attitude to it must, perhaps, be the concern of religion rather than rational philosophy. ${ }^{29}$ In some later writings, too, Putnam (arguing against, say, what he regards as

28 I have tried to argue for the entanglement of pragmatism with Kantian transcendental thinking in several previous works, including most recently in Pihlström, Pragmatic Pluralism and the Problem of God, especially chapter 1.

${ }^{29}$ Hilary Putnam, Realism and Reason (Cambridge: Cambridge University Press, 1983), p. 226. 
pseudo-Wittgensteinian relativistic 'language-game theology') seems to maintain that a realistic attitude to what religious perspectives are perspectives on is a presupposition of making sense of religious and theological language-use: 'A perspective on something cannot simply be "constructed"; if it is to be a perspective at all, it must be constrained by what it depicts [...]. ${ }^{30}$

Insofar as such a realistic postulation of a transcendent reality of religion cannot really be spoken about in any normal language, pragmatic realism cannot be committed to any strong epistemological realism (or even semantic realism) about the transcendent. It can only incorporate a minimal assumption of ontological realism regarding transcendence, along with a fallibilist recognition of the possible recognitiontranscendence of any truths (or falsities) about it. There is something out there that we may have to postulate insofar as our religious attitudes are to have any sense in our practices (or to be sensibly denied), but we need to recognize that such postulations could always be completely mistaken. It is in terms of pragmatism itself that this kind of theological, religious, and philosophical attitudes and their presuppositions are to be critically evaluated.

Acknowledgment. Early versions of this essay were presented at the Templeton Summer School on theological realism in Mainz, Germany, in September 2013; and at the Estonian Philosophy Conference in Tallinn, December 2013 (in a session honouring Rein Vihalemm and his 'practical realism'). I am indebted to Oliver Wiertz, Thomas Schmidt, Philip Rossi, Kenneth R. Westphal, as well as the audiences of the Mainz and Tallinn events for insightful comments and criticism.

${ }^{30}$ Hilary Putnam, 'On Negative Theology', Faith and Philosophy, 14 (1997), 407-422. 